\title{
EDITORIAL
}

\section{Thirty years of Bone Marrow Transplantation}

Bone Marrow Transplantation (2016) 51, 1411-1412; doi:10.1038/ bmt.2016.175; published online 4 July 2016

Thirty years ago, Professor John Goldman of Hammersmith Hospital called me in the evening in my Los Angeles home. It was 0200 hours in London. John and I were close friends so it was no surprise; these were his prime working hours. John said he was speaking to colleagues at Macmillan Publishers Limited, owners of the Nature Publishing Group, regarding the possibility of starting a journal focused on bone marrow transplantation. He chose Macmillan because of their distinguished publishing labels including Farrar, Straus and Giroux, Henry Holt, Scientific American and Picador among others. This was 1985 and transplantation was at a relatively early stage. John was convinced that our field needed a dedicated forum for the exchange of data and ideas. He was, of course, entirely correct but met initial resistance regarding the need for a specialty journal in an exotic field of medicine.

I immediately realized that John was on the right track, and a teleconference with Alex Williamson of the Nature Publishing Group was held (Today we would use FaceTime but at that time the Dick Tracy like concept was unimaginable.) Alex was duly persuaded and helped us present the concept to her superiors, who agreed. Bone Marrow Transplantation was born and, as they say, the rest is history.

Our Nature colleagues were concerned that the journal should be read globally rather than solely in European countries, and John kindly asked me to serve as co-Editor. The first Associate Editors were Eliane Gluckman, Alberto Marmont, Tohru Masaoka, George Santos, E. Donnall Thomas and Jon van Rood. John invited a distinguished Editorial Board of 79 colleagues. As I review the list today I see John's prescience. Each was an extraordinarily talented scientist/clinician who went on to star in our field. These persons bought into John's idea and contributed greatly to the success of the journal. Some have retired or sadly left us to be replaced by equally brilliant and dedicated younger colleagues.

Alex Williamson stayed on for several years as our liaison with the Nature Publishing Group. She was followed by Jayne Marks, Katherine Hinton and, in 2009, by Lucinda Haines. All have been strong supporters of the journal and have always ably presented our case to the publisher, who recently merged with Springer to become Springer Nature.

Several others deserve a special mention on this occasion. Linda Casey, based at Hammersmith Hospital, was the journal's editorial assistant, and later editorial coordinator for 25 years and was John's gal Friday. Linda was a tireless advocate of the journal and did much of the heavy-lifting. I should also acknowledge the contributions of Myrtle Gordon and Jennifer Treleaven who joined us as Assistant Editors in 1992 and who translated many typescripts ostensibly written in English to English English. As Oscar Wilde said: 'We have really everything in common with America nowadays except, of course, language.' Myrtle continues to keep an eye on authors' proofs as they progress through the editorial system. In 1998, Hillard Lazarus took responsibility for commissioning review typescripts, which have helped the journal greatly.

Bone Marrow Transplantation Volume 1 was launched in May 1986 (Figure 1). There was an editorial by John, three reviews and nine original articles. The topics are not terribly dissimilar to issues we debate today and included typescripts from Jane Apperley,
Sante, Tura, Ole Ringdon, Andrea Bacigalupo, Ted Gordon-Smith, Eliane Gluckman, David Galton and me, amongst others. Not a bad start. In 1995 Bone Marrow Transplantation was designated as the official journal of the European Society for Blood and Marrow Transplantation, an organisation John helped found in 1974 and of which he was President (1990-1994).

A word regarding the much admired covers. On the first issue, and for the next 3 years, showed photomicrographs of haematopoietic cells. One panel showed a killer cell (today termed a natural killer or NK cell), which the legend stated: may be involved in the pathogenesis of GvHD. It seems Bone Marrow Transplantation was already ahead of its time. In 1989 John had the innovative, perhaps brilliant idea of switching to art and changing the cover at regular intervals. His first choice was a copy of Lamelles by Sonia Delaunay, which hung in his home in Notting Hill (Figure 2). John was a great fan of her and her husband Robert. Over the next years the cover changed every 6 months. This required considerable effort by John and especially Linda Casey. John would select the painting and give a picture postcard or catalogue of it to Linda who had to locate the copyright holder, apply for permissions and reduce the artist's biography to about 150 words. Not so easy when the artist is Vincent van Gogh. However, John felt art and science should be mixed for the best effect (He read classics at Oxford before he transferred to medicine, could read ancient Greek and often listened to Shakespeare on headphones whilst editing.)

Next, a word about the technology (perhaps a euphemism) of publication in the Dark Ages. The Journal began with Linda Casey's hand-written details of submissions in a ledger along with details of reviewers, decisions and so on. At least it was not a

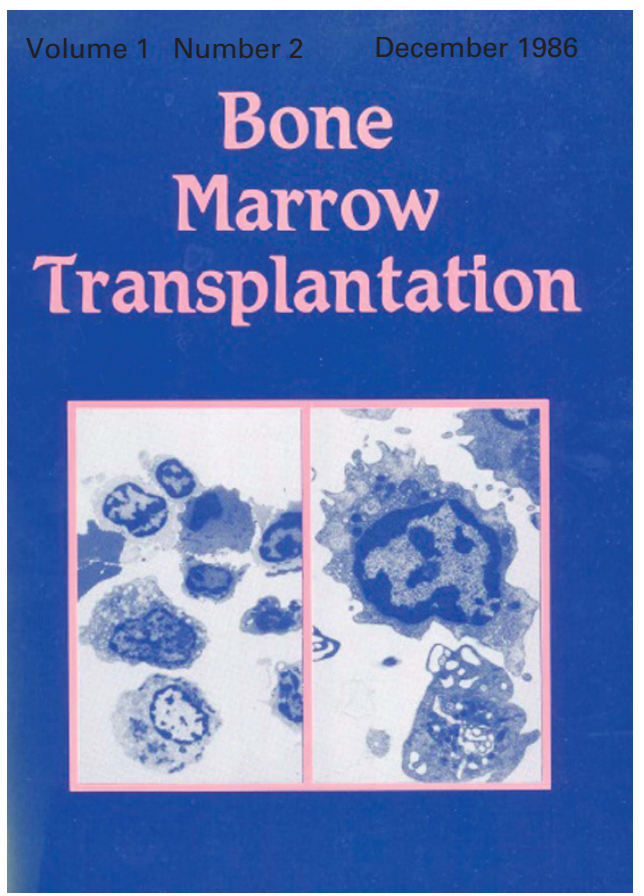

Figure 1. Front cover of the first volume of Bone Marrow Transplantation, published on May 1986. 


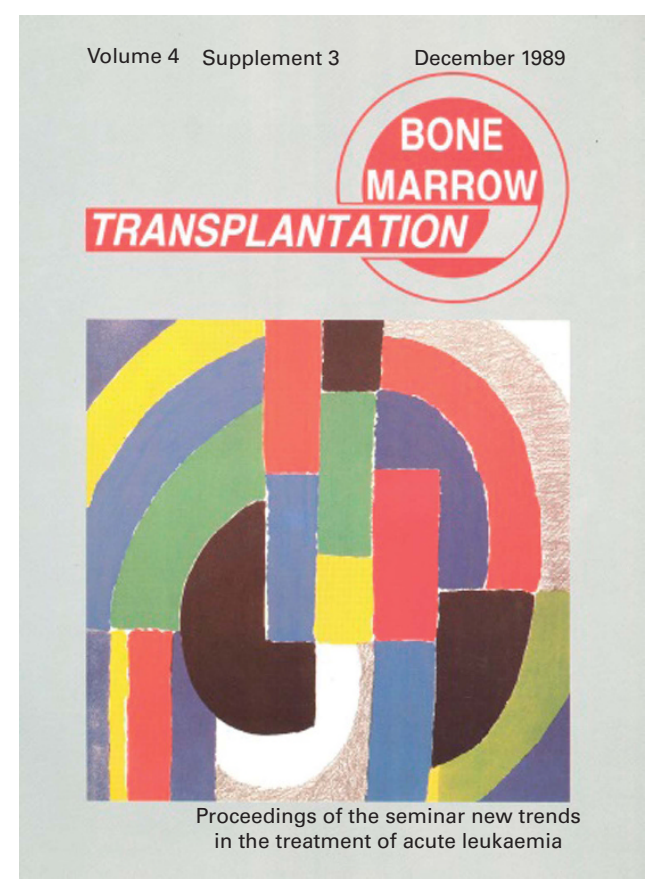

Figure 2. Front cover of Bone Marrow Transplantation incorporating the art Lamelles by Sonia Delaunay.

stone tablet. Stationery was supplied by the Publisher including three-part carbonless review forms. The journal soon introduced a word-processing-based recording system and a simple database used by Linda for many years. The journal went online in 2003 preceded by several months' intensive work in collaboration with the Nature Publishing Group. The system we now have, albeit imperfect, is light years ahead of where we were.

Although many people contributed to the early and on-going success of Bone Marrow Transplantation, there was never any question whether this was John's baby. His untimely, sudden death in 2013 shocked and saddened the global haematology community - a great loss. However, we never doubted the journal would survive and we were able to identify two able new co-editors: Hillard Lazarus from the United States and Mohamad Mohty from France. These youngsters have brought renewed vigour to the journal, added new Editorial Board members, new types of articles and reports, decreased publication times and, the holy grail, increased the Impact Factor (3.570 and climbing). They have wisely transferred me to Executive Editor where I can do little harm.

In his inaugural editorial John said, 'As the volume of medical and scientific literature expands relentlessly those responsible for the conception and eventual birth of yet another journal must satisfy themselves that their goals are not purely commercial or egotistical. Where the experimental and clinical aspects of Bone Marrow Transplantation are concerned we believe one can make a reasonable case for bringing together under a single cover the wealth of data that continues to accumulate. This much perhaps is obvious. Whether this belief is valid, only time will tell.'

History has spoken in the form of the continued success and contribution of Bone Marrow Transplantation to progress in our field. The journal is now in its fifty-first volume having published almost 30000 scientific articles, commentaries, reviews, editorials and the like. Quite a track record and the future looks even brighter.

I'm certain that John is looking down on all this with great pride. (With his wry sense of humour he might say looking up.) It must be greatly satisfying for an educator like John Goldman to see the resilience of his creation. Hillard, Mohamad and I look forward to another successful 30 years. (I, more likely than John, will be looking up.) I am only sorry John is not here to celebrate with us.

\section{CONFLICT OF INTEREST}

The author declares no conflict of interest.

RP Gale

Haematology Research Centre, Division of Experimental Medicine, Department of Medicine, Imperial College London, London, UK E-mail: robertpetergale@gmail.com 